\title{
Marinimicrobium koreense gen. nov., sp. nov. and Marinimicrobium agarilyticum sp. nov., novel moderately halotolerant bacteria isolated from tidal flat sediment in Korea
}

\author{
Jee-Min Lim, ${ }^{1}$ Che Ok Jeon, ${ }^{2}$ Jae-Chan Lee, ${ }^{1}$ Sung-Min Song, ${ }^{1,3}$ \\ Kwang-Yup $\mathrm{Kim}^{3}$ and Chang-Jin Kim ${ }^{1}$ \\ ${ }^{1}$ Korea Research Institute of Bioscience and Biotechnology, 52 Oeundong, Yusong, Daejeon \\ 305-333, Republic of Korea \\ ${ }^{2}$ Environmental Biotechnology National Core Research Center, PMBBRC, Division of \\ Environmental Biotechnology, Gyeongsang National University, 660-701, Republic of Korea \\ ${ }^{3}$ Department of Food Science and Technology, Chungbuk National University, Cheongju \\ 361-763, Republic of Korea
}

Correspondence

Chang-Jin Kim

changjin@kribb.re.kr
Two moderately halotolerant Gram-negative bacteria were isolated from tidal flat sediment of the South Sea in Korea (the Korea Strait). The strains, designated $\mathrm{M}^{\top}$ and $\mathrm{M} 18^{\top}$, were strictly aerobic, rod-shaped and non-spore-forming and motile with a flagellum and their major fatty acids were $\mathrm{C}_{16: 0}$ and $\mathrm{C}_{19: 0}$ cyclo $\omega 8 \mathrm{c}$. Strains $\mathrm{M9}^{\top}$ and $\mathrm{M} 18^{\top}$ could grow in the presence of up to $13-15 \%$ $(\mathrm{w} / \mathrm{v}) \mathrm{NaCl}$, but their optimum salt concentrations were relatively low $(0-3 \%, \mathrm{w} / \mathrm{v})$. The major predominant isoprenoid quinone was $\mathrm{Q}-8$ and the $\mathrm{G}+\mathrm{C}$ content of the genomic DNA was 57-58 mol\%. Phylogenetic analyses and comparative 16S rRNA gene sequence studies revealed that strains $M 9^{\top}$ and $M 18^{\top}$ formed a phylogenetic lineage distinct from the genus Teredinibacter within the class Gammaproteobacteria and were most closely related to the genera Microbulbifer, Saccharophagus and Teredinibacter, with less than 92.5\% 16S rRNA gene sequence similarity. The level of $16 \mathrm{~S}$ rRNA gene sequence similarity between the two strains was $96 \cdot 7 \%$. On the basis of physiological and phylogenetic properties, strains $M 9^{\top}$ and $M 18^{\top}$ represent separate species within a novel genus of the class Gammaproteobacteria, for which the names Marinimicrobium koreense gen. nov., sp. nov. (type species) and Marinimicrobium agarilyticum sp. nov. are proposed. The type strains of Marinimicrobium koreense and Marinimicrobium agarilyticum are $\mathrm{M9}^{\top}\left(=\mathrm{KCTC} 12356^{\top}=\mathrm{DSM} 16974^{\top}\right)$ and $\mathrm{M}^{\top} 8^{\top}\left(=\mathrm{KCTC} 12357^{\top}=\mathrm{DSM}\right.$ $\left.16975^{\top}\right)$, respectively.
Gram-negative bacteria belonging to the class Gammaproteobacteria are attracting interest because this group of bacteria has great biotechnological potential for production of hydrolytic enzymes (Howard et al., 2004; Martín et al., 2003) and many novel species have recently been added to the genera (Gorshkova et al., 2003; Romanenko et al., 2005; Satomi et al., 1998, 2004; Shivaji et al., 2005; Yoon et al.,

Published online ahead of print on 25 November 2005 as DOI 10.1099/ijs.0.64075-0.

The GenBank accession numbers for the $16 \mathrm{~S}$ rRNA gene sequences of strains $\mathrm{M}^{\top}$ and $\mathrm{M}^{\top} 8^{\top}$ are $\mathrm{AY} 839869$ and $\mathrm{AY} 839870$.

An electron micrograph of a cell of strain $M 18^{\top}$, a photograph of colonies showing agarolytic activity and details of other properties of the novel isolates are available as supplementary material in IJSEM Online.
2004). For example, Microbulbifer hydrolyticus isolated from a lignin-rich pulp mill waste is capable of degrading lignin and lignin-like polymers and Marinobacter hydrocarbonoclasticus, with hydrocarbon-degrading activity, was isolated from an oil-producing well on an offshore platform in southern Vietnam (Huu et al., 1999; González et al., 1997; Gauthier et al., 1992; Marquez \& Ventosa, 2005). In addition, Distel et al. (2002) isolated a moderate halophile, Teredinibacter turnerae $\mathrm{T} 7902^{\mathrm{T}}$, with cellulolytic activity from gill tissue of the shipworm. In this paper, we report the isolation of two novel moderately halotolerant, Gram-negative bacteria (strains $\mathrm{M} 9^{\mathrm{T}}$ and $\mathrm{M} 18^{\mathrm{T}}$ ) from tidal flat sediment in Korea; strain $\mathrm{M} 18^{\mathrm{T}}$ showed agar-dissolving activity. We determined their phylogenetic position using a polyphasic approach as members of two different species within a new genus of the class Gammaproteobacteria. 
Two strains, $\mathrm{M} 9^{\mathrm{T}}$ and $\mathrm{M} 18^{\mathrm{T}}$, were isolated from a tidal flat of Jeonnam province in the South Sea of Korea (the Korea Strait). For isolation, sediment sample was collected from the surface of tidal flat sediment and diluted serially in saline solution $(10 \% \mathrm{w} / \mathrm{v})$. The diluted soil samples were spread on marine agar 2216 (MA) (Difco) with the addition of $8 \%$ $(\mathrm{w} / \mathrm{v}) \mathrm{NaCl}$ (final concentration, $9.94 \% \mathrm{w} / \mathrm{v} \mathrm{NaCl}$ ) and incubated for 2 days at $30^{\circ} \mathrm{C}$. The isolates were routinely cultivated on MA for 2 days at $35^{\circ} \mathrm{C}$ except where indicated otherwise. Requirement for and tolerance of $\mathrm{NaCl}$ were determined in trypticase soy broth (Difco) medium with different amounts of $\mathrm{NaCl}$ after 2 days incubation at $35^{\circ} \mathrm{C}$. Anaerobic growth was determined by incubation in an anaerobic chamber at $35^{\circ} \mathrm{C}$ for 5 days on MA. Optimum growth was tested at different temperatures $\left(4-55^{\circ} \mathrm{C}\right)$ on $\mathrm{MA}$ and at different $\mathrm{pH}$ values $(5 \cdot 0-10 \cdot 0)$ in marine broth.

Gram staining was determined using the bioMérieux Gram stain kit according to the manufacturer's instructions. Catalase activity was determined by production of oxygen bubbles in $3 \%(\mathrm{v} / \mathrm{v})$ aqueous hydrogen peroxide solution. Oxidase activity was tested by oxidation of $1 \%(\mathrm{w} / \mathrm{v})$ tetramethyl-p-phenylenediamine (Merck). Nitrate reduction was assessed according to the method of Lanyi (1987). Hydrolysis of aesculin, casein, starch, Tween 20, Tween 80, hypoxanthine, tyrosine, gelatin, agar and xanthine was determined on MA according to the methods described by Cowan \& Steel (1965), Lanyi (1987) and Gerhardt et al. (1994). The API ZYM system (bioMérieux) was used to determine the activities of some enzymes. Acid production from carbohydrates was tested as described by Leifson (1963); all suspension media were supplemented with artificial sea water containing $2 \%(\mathrm{w} / \mathrm{v}) \mathrm{NaCl}$.

Cell morphology was studied using light microscopy and transmission electron microscopy. Motility was observed at 12 and $36 \mathrm{~h}$ on agar-coated wet mounts with a light microscope (Nikon E600). Agar-coated wet mounts for motility observations were prepared by placing $10 \mu \mathrm{l}$ of a culture under a cover glass on a glass slide previously coated with a film of $0.5 \%(\mathrm{w} / \mathrm{v})$ agarose (Cambrex) in distilled water and air-dried. For investigation of flagellum type from the isolates, specimens were prepared from the exponential growth phase as described elsewhere (Lee et al., 2005) and then subjected to transmission electron microscopy (JEOL JEM1010). Whole-cell fatty acids of strains $\mathrm{M} 9^{\mathrm{T}}$ and $\mathrm{M} 18^{\mathrm{T}}$ were analysed using GC/MS following the instructions of the Microbial Identification System (MIDI; Microbial ID, Inc.) after cultivation on MA for 2 days at $35^{\circ} \mathrm{C}$. Isoprenoid quinones and polar lipids were analysed as described by Komagata \& Suzuki (1987). The DNA G +C content of strains $\mathrm{M}^{\mathrm{T}}$ and $\mathrm{M} 18^{\mathrm{T}}$ was determined by reversed-phase HPLC, using the method of Tamaoka \& Komagata (1984).

The 16S rRNA gene sequences of strains $\mathrm{M}^{\mathrm{T}}$ and $\mathrm{M} 18^{\mathrm{T}}$ were analysed as described previously (DeLong, 1992). The resultant 16S rRNA gene sequences of strains $\mathrm{M}^{\mathrm{T}}$ and $\mathrm{M} 18^{\mathrm{T}}$ for phylogenetic analysis comprised 1454 and 1455 nucleotides, respectively, and were compared with available sequences from GenBank using the BLAST program (http:// www.ncbi.nlm.nih.gov/blast/) to determine the approximate phylogenetic affiliation. They were aligned with sequences from closely related organisms using the CLUSTAL W software (Thompson et al., 1994). Unmatched regions of the 5' and 3' ends from the alignment, which were caused by the different lengths of the 16S rRNA gene sequences, were deleted. Phylogenetic trees based on 16S rRNA gene sequences were constructed using three different methods, neighbourjoining (NJ), maximum-likelihood (ML) and maximumparsimony (MP) algorithms available in the PHYLIP software, version 3.6 (Felsenstein, 2002). Using the FASTA3 program in EBI, 16S rRNA gene sequence comparisons for similarity calculations were made between the isolated strains and other related organisms. A bootstrap analysis was performed according to the algorithm of the Kimura two-parameter model (Kimura, 1980) of the neighbour-joining method in the PHYLIP package.

Cells of strains $\mathrm{M} 9^{\mathrm{T}}$ and $\mathrm{M} 18^{\mathrm{T}}$ were non-spore-forming, short rods, approximately $0 \cdot 5-0 \cdot 8 \times 0 \cdot 9-1 \cdot 1 \mu \mathrm{m}$ and $0 \cdot 6-$ $0.7 \times 0.9-1.5 \mu \mathrm{m}$, respectively (Supplementary Fig. S1 available in IJSEM Online). They were aerobic, Gramnegative, catalase-negative and motile with a flagellum. Colonies of strains $\mathrm{M} 9^{\mathrm{T}}$ and $\mathrm{M} 18^{\mathrm{T}}$ were creamy, smooth, glistening, low-convex and circular/slightly irregular.

Table 1. Cellular fatty acid content of strains $M 9^{\top}$ and $M 18^{\top}$

Data are expressed as percentages of total fatty acids. Fatty acids representing less than $0 \cdot 5 \%$ are not included.

\begin{tabular}{|lcc|}
\hline Fatty acid & Strain $^{\text {M9 }}{ }^{\mathbf{T}}$ & Strain $^{\mathbf{M 1 8}^{\mathbf{T}}}$ \\
\hline Saturated & & \\
$\mathrm{C}_{9: 0}$ & $0 \cdot 68$ & $0 \cdot 15$ \\
$\mathrm{C}_{10: 0}$ & $3 \cdot 34$ & $7 \cdot 65$ \\
$\mathrm{C}_{10: 0} 3-\mathrm{OH}$ & $5 \cdot 31$ & $5 \cdot 79$ \\
$\mathrm{C}_{11: 0}$ & $1 \cdot 20$ & $0 \cdot 41$ \\
$\mathrm{C}_{11: 0} 3-\mathrm{OH}$ & $0 \cdot 58$ & $0 \cdot 14$ \\
$\mathrm{C}_{12: 0}$ & $1 \cdot 54$ & $0 \cdot 55$ \\
$\mathrm{C}_{14: 0}$ & $3 \cdot 08$ & $0 \cdot 92$ \\
$\mathrm{C}_{15: 0}$ & $5 \cdot 71$ & $1 \cdot 10$ \\
$\mathrm{C}_{16: 0}$ & $24 \cdot 46$ & $26 \cdot 02$ \\
$\mathrm{C}_{17: 0}$ & $4 \cdot 24$ & $2 \cdot 26$ \\
$\mathrm{C}_{17: 0}$ cyclo & $1 \cdot 09$ & $0 \cdot 58$ \\
$\mathrm{C}_{18: 0}$ & $2 \cdot 64$ & $3 \cdot 59$ \\
$\mathrm{C}_{19: 0}$ cyclo $\omega 8 c$ & $22 \cdot 38$ & $22 \cdot 99$ \\
Unsaturated & & \\
$\mathrm{C}_{17: 1} \omega 8 c$ & $0 \cdot 70$ & $0 \cdot 26$ \\
$\mathrm{C}_{18: 1} \omega 7 c$ & $3 \cdot 46$ & $5 \cdot 30$ \\
$11-$ Methyl $\mathrm{C}_{18: 1} \omega 7 c$ & $1 \cdot 01$ & $0 \cdot 58$ \\
Summed features & & $18 \cdot 05$ \\
Summed feature $3 *$ & $15 \cdot 55$ & \\
& & \\
\hline
\end{tabular}

* Summed features represent groups of two or three fatty acids that could not be separated by GLC with the MIDI system. Summed feature 3 contained $\mathrm{C}_{16: 1} \omega 7 c$ and/or iso $\mathrm{C}_{15: 0} 2-\mathrm{OH}$. 
Growth of strains $\mathrm{M} 9^{\mathrm{T}}$ and $\mathrm{M} 18^{\mathrm{T}}$ was not observed under anaerobic conditions. Strains $\mathrm{M} 9^{\mathrm{T}}$ and $\mathrm{M} 18^{\mathrm{T}}$ showed optimum growth at low $\mathrm{NaCl}$ concentrations of 1-3 and $0-1 \%(\mathrm{w} / \mathrm{v})$, respectively. However, they could grow in the presence of up to $13-15 \%(\mathrm{w} / \mathrm{v}) \mathrm{NaCl}$, meaning that they are moderately halotolerant. Strains $\mathrm{M} 9^{\mathrm{T}}$ and $\mathrm{M} 18^{\mathrm{T}}$ grew in the range of pH $6 \cdot 0-10 \cdot 5$ in marine broth; optimal growth was observed at $\mathrm{pH} 7 \cdot 0-7 \cdot 5$ and $7 \cdot 0-8 \cdot 0$, respectively. The isolates displayed mesophilic growth, with optimum growth at $35-40{ }^{\circ} \mathrm{C}$.

The predominant isoprenoid quinone of strains $\mathrm{M}^{\mathrm{T}}$ and $\mathrm{M}^{\mathrm{T}}{ }^{\mathrm{T}}$ was ubiquinone-8 (Q-8). The genomic DNA G $+\mathrm{C}$ contents of strains $\mathrm{M}^{\mathrm{T}}$ and $\mathrm{M} 18^{\mathrm{T}}$ were respectively 57 and $58 \mathrm{~mol} \%$. Strains $\mathrm{M}^{\mathrm{T}}$ and $\mathrm{M} 18^{\mathrm{T}}$ contained $\mathrm{C}_{16: 0}, \mathrm{C}_{19: 0}$ cyclo $\omega 8 c$ and summed feature $3\left(\mathrm{C}_{16: 1} \omega 7 c\right.$ and/or iso $\mathrm{C}_{15: 0}$ 2-OH) as the major cellular fatty acids on MA, but their fatty acid profiles were slightly different (Table 1). Most cultural and biochemical characteristics of strains $\mathrm{M} 9^{\mathrm{T}}$ and $\mathrm{M} 18^{\mathrm{T}}$ were similar, but there were some differences. For example, cells of strain $\mathrm{M}^{\mathrm{T}}$ showed an oxidase-negative reaction, but those of strain $\mathrm{M} 18^{\mathrm{T}}$ were oxidase-positive. Strain $\mathrm{M}^{\mathrm{T}}$ contained large amounts of phosphatidylethanolamine and diphosphatidylglycerol and small amounts of two unknown phospholipids (PL1, PL2) as the polar lipids, while strain $\mathrm{M} 18^{\mathrm{T}}$ contained only a large amount of phosphatidylethanolamine and a small amount of diphosphatidylglycerol (data not shown). Strain $\mathrm{M} 18^{\mathrm{T}}$ also hydrolysed agar, whereas strain $\mathrm{M}^{\mathrm{T}}$ did not (Supplementary Fig. S2). In enzyme production, such as $\alpha$ - and $\beta$-galactosidase and $\alpha$ glucosidase activities, they also had a few different characteristics. Further physiological and biochemical characteristics of strains $\mathrm{M}^{\mathrm{T}}$ and $\mathrm{M} 18^{\mathrm{T}}$ are compared in detail in the species descriptions and in Supplementary Table S1. Other morphological, physiological and biochemical characteristics of strains $\mathrm{M}^{\mathrm{T}}$ and $\mathrm{M} 18^{\mathrm{T}}$ are compared with those of phylogenetically related type strains in Table 2 .

Almost complete 16S rRNA gene sequences of strains $\mathrm{M}^{\mathrm{T}}$ and $\mathrm{M} 18^{\mathrm{T}}$ were obtained and used for initial BLAST searches in GenBank and further phylogenetic analyses. The tree constructed by the NJ method using $16 \mathrm{~S}$ rRNA gene sequences showed that strains $\mathrm{M}^{\mathrm{T}}$ and $\mathrm{M} 18^{\mathrm{T}}$ formed a phylogenetic lineage distinct from the genera Microbulbifer, Saccharophagus and Teredinibacter within the class Gammaproteobacteria, with a bootstrap value of $64 \%$ (Fig. 1). The topologies of

Table 2. Differential phenotypic characteristics of strains $M 9^{\top}$ and $M 18^{\top}$ and related type strains

Strains: 1, Microbulbifer maritimus TF- $17^{\mathrm{T}}$ (data from Yoon et al., 2004); 2, Microbulbifer hydrolyticus DSM 11525 ${ }^{\mathrm{T}}$ (Gonzalez et al., 1997); 3, Microbulbifer elongatus DSM 6810 ${ }^{\mathrm{T}}$ (Yoon et al., 2003b); 4, Microbulbifer salipaludis SM- ${ }^{\mathrm{T}}$ (Yoon et al., 2003a); 5, Teredinibacter turnerae $\mathrm{T}_{7902}{ }^{\mathrm{T}}$ (Distel et al., 2002); 6, Saccharophagus degradans 2-40 (Ekborg et al., 2005). +, Positive; -, negative; W, weakly positive; ND, not determined.

\begin{tabular}{|c|c|c|c|c|c|c|c|c|}
\hline Characteristic & $\mathrm{M9}^{\mathrm{T}}$ & $\mathrm{M}_{18^{\mathrm{T}}}$ & 1 & 2 & 3 & 4 & 5 & 6 \\
\hline Morphology & Short rod & Short rod & Rod & Rod & Coccus or rod & Rod & Rod & $\begin{array}{c}\text { Pleomorphic } \\
\text { rod }\end{array}$ \\
\hline Catalase & - & - & ND & + & + & + & + & + \\
\hline Oxidase & - & + & + & + & ND & + & + & + \\
\hline Agar & - & + & - & - & + & $\mathrm{w}$ & - & ND \\
\hline Gelatin & - & - & + & + & + & $\mathrm{ND}$ & $\mathrm{ND}$ & ND \\
\hline Tween 80 & - & + & + & + & $\mathrm{ND}$ & + & $\mathrm{ND}$ & $\mathrm{ND}$ \\
\hline Aesculin & + & + & - & + & $\mathrm{ND}$ & + & $\mathrm{ND}$ & $\mathrm{ND}$ \\
\hline Casein & - & - & + & + & $\mathrm{ND}$ & $\mathrm{w}$ & $\mathrm{ND}$ & ND \\
\hline Fructose & + & + & $\mathrm{ND}$ & $\mathrm{ND}$ & $\mathrm{ND}$ & - & + & $\mathrm{ND}$ \\
\hline Lactose & + & + & $\mathrm{ND}$ & ND & $\mathrm{ND}$ & - & $\mathrm{ND}$ & ND \\
\hline Mannitol & - & - & - & $\mathrm{ND}$ & $\mathrm{ND}$ & - & $\mathrm{ND}$ & $\mathrm{ND}$ \\
\hline Mannose & + & + & $\mathrm{ND}$ & $\mathrm{ND}$ & $\mathrm{ND}$ & - & $\mathrm{ND}$ & $\mathrm{ND}$ \\
\hline Sucrose & + & + & - & - & + & - & + & $\mathrm{ND}$ \\
\hline Major fatty $\operatorname{acid}(\mathrm{s})$ & $\begin{array}{c}\mathrm{C}_{16: 0}, \mathrm{C}_{19: 0} \\
\text { cyclo } \omega 8 c\end{array}$ & $\begin{array}{c}\mathrm{C}_{16: 0}, \mathrm{C}_{19: 0} \\
\text { cyclo } \omega 8 c\end{array}$ & iso- $\mathrm{C}_{15: 0}$ & $\begin{array}{l}\text { iso- } \mathrm{C}_{15: 0} \\
\text { iso- } \mathrm{C}_{17: 1} \omega 9 c\end{array}$ & iso- $\mathrm{C}_{15: 0}$ & $\begin{array}{c}\text { iso- } \mathrm{C}_{15: 0} \\
\mathrm{C}_{16: 0}\end{array}$ & $\mathrm{ND}$ & iso- $C_{16: 0}$ \\
\hline DNA G $+\mathrm{C}$ content $(\mathrm{mol} \%)$ & 57 & 58 & $59 \cdot 9$ & $57 \cdot 7$ & $\mathrm{ND}$ & 59 & $49-51$ & $45 \cdot 8$ \\
\hline
\end{tabular}


phylogenetic trees built using the ML and MP algorithms also supported the conclusion that strains $\mathrm{M}^{\mathrm{T}}$ and $\mathrm{M} 18^{\mathrm{T}}$ formed a phylogenetic line distinct from these genera (data not shown). Comparative 16S rRNA gene sequence analyses showed that strains $\mathrm{M} 9^{\mathrm{T}}$ and $\mathrm{M} 18^{\mathrm{T}}$ were most closely related to members of the genera Microbulbifer, Saccharophagus and Teredinibacter, with no more than $92.5 \% 16 \mathrm{~S}$ rRNA gene sequence similarity. The level of 16S rRNA gene sequence similarity between strains $\mathrm{M} 9^{\mathrm{T}}$ and $\mathrm{M} 18^{\mathrm{T}}$ was $96 \cdot 7 \%$, which suggests that the strains should be classified within the same genus and different species (Rossello-Mora \& Amann, 2001; Stackebrandt et al., 2002). Therefore, on the basis of physiological and molecular properties, strains $\mathrm{M}^{\mathrm{T}}$ and $\mathrm{M} 18^{\mathrm{T}}$ represent a novel genus, Marinimicrobium gen. nov., and two different species within the class Gammaproteobacteria, for which the names Marinimicrobium koreense gen. nov., sp. nov. and Marinimicrobium agarilyticum sp. nov. are proposed.

\section{Description of Marinimicrobium gen. nov.}

Marinimicrobium (Ma.ri.ni.mi.cro'bi.um. L. adj. marinus of the sea; N.L. neut. n. microbium microbe; N.L. neut. n. Marinimicrobium microbe living in the sea).

Strictly aerobic, chemoheterotrophic and moderately halotolerant. Colonies are creamy, smooth, glistening and circular/slightly irregular. Cells are Gram-negative,

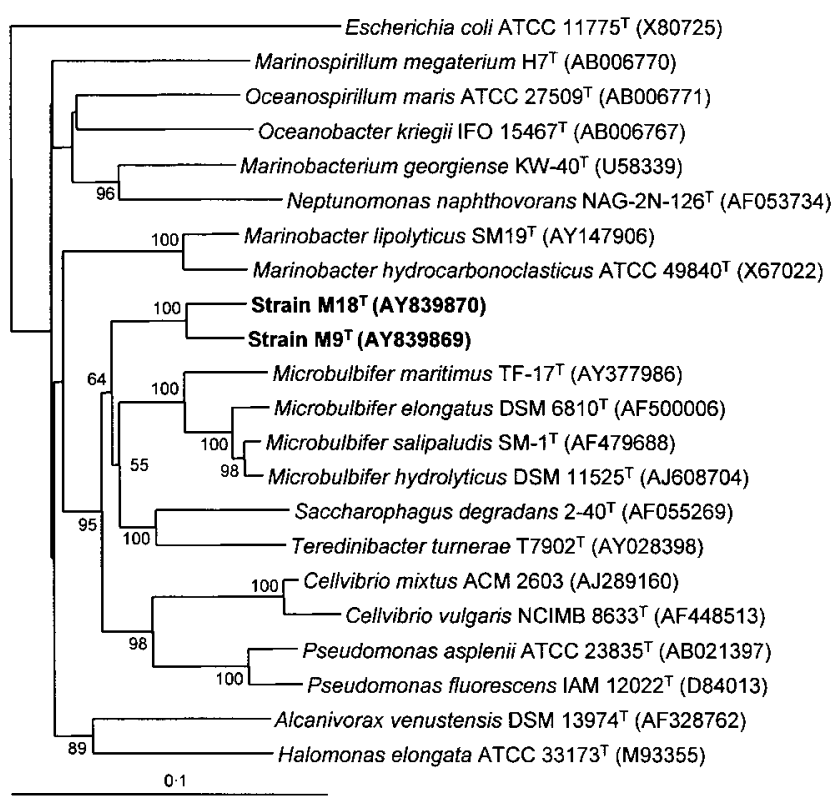

Fig. 1. Neighbour-joining tree showing the phylogenetic relationships based on $16 \mathrm{~S}$ rRNA gene sequences of strains $\mathrm{M9}^{\top}$ and $M 18^{\top}$ and other related taxa. Bootstrap values are shown as percentages of 1000 replicates, when more than $50 \%$. Escherichia coli ATCC $11775^{\top}$ was used as an outgroup. Bar, $0 \cdot 1$ changes per nucleotide position. non-spore-forming, short rods, approximately $0 \cdot 5-0 \cdot 8 \mu \mathrm{m}$ wide and $0 \cdot 9-1 \cdot 5 \mu \mathrm{m}$ long. Nitrate is not reduced to nitrite. Cells are motile by means of a flagellum. Catalase-negative. The predominant isoprenoid quinone is Q-8. The major fatty acids are $\mathrm{C}_{16: 0}, \mathrm{C}_{19: 0}$ cyclo $\omega 8 c$ and summed feature $3\left(\mathrm{C}_{16: 1} \omega 7 c\right.$ and/or iso $\left.\mathrm{C}_{15: 0} 2-\mathrm{OH}\right)$. The $\mathrm{G}+\mathrm{C}$ content of the genomic DNA is $57-58 \mathrm{~mol} \%$ (HPLC). Phylogenetically, the genus belongs to the class Gammaproteobacteria. The type species is Marinimicrobium koreense.

\section{Description of Marinimicrobium koreense sp. nov.}

Marinimicrobium koreense (ko.re.en'se. N.L. neut. adj. koreense pertaining to Korea).

Growth of cells occurs at salinities in the range $0-15 \%(\mathrm{w} / \mathrm{v})$ $\mathrm{NaCl}$ (optimum 1-3\% w/v). Oxidase-negative. Grows at between 10 and $45^{\circ} \mathrm{C}$ (optimum $35-40{ }^{\circ} \mathrm{C}$ ) and from $\mathrm{pH} 6 \cdot 0$ to $10 \cdot 5$ (optimum $\mathrm{pH} 7 \cdot 0-7 \cdot 5$ ). API ZYM kit gives positive results for alkaline phosphatase, esterase (C4), esterase lipase, leucine arylamidase, valine arylamidase, naphthol-AS-BIphosphohydrolase, $\alpha$-galactosidase, $\alpha$-glucosidase and $N$ acetyl- $\beta$-glucosaminidase and negative results for lipase, cystine arylamidase, trypsin, $\alpha$-chymotrypsin, acid phosphatase, $\beta$-galactosidase, $\beta$-glucuronidase, $\beta$-glucosidase, $\alpha$-mannosidase and $\alpha$-fucosidase. Aesculin, starch and Tween 20 are hydrolysed. Casein, gelatin, L-tyrosine, xanthine and Tween 80 are not hydrolysed. Acids are produced from D-glucose, D-fructose, D-ribose, D-xylose, $\alpha$-D-lactose, maltose, D-trehalose, L-arabinose, D-melibiose, D-mannose and sucrose, but not from D-mannitol, adonitol, raffinose, glycerol or inositol. Shows no agarolytic activity. Contains large amounts of phosphatidylethanolamine and diphosphatidylglycerol and small amounts of two unknown phospholipids (PL1, PL2) as the polar lipids. The DNA G + C content is $57 \mathrm{~mol} \%$.

The type strain is strain $\mathrm{M}^{\mathrm{T}}\left(=\mathrm{KCTC} 12356^{\mathrm{T}}=\mathrm{DSM}\right.$ $\left.16974^{\mathrm{T}}\right)$, isolated from tidal flat sediment in Korea.

\section{Description of Marinimicrobium agarilyticum sp. nov.}

Marinimicrobium agarilyticum (a.ga.ri.ly'ti.cum. N.L. n. agarum agar; N.L. adj. lyticus from Gr. adj. lutikos dissolving; N.L. neut. adj. agarilyticum agar-dissolving).

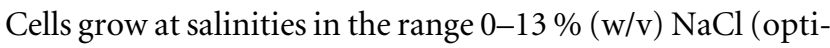
mum $0-1 \% \mathrm{w} / \mathrm{v})$. Oxidase-positive. Grows at between 12 and $40^{\circ} \mathrm{C}$ (optimum $35^{\circ} \mathrm{C}$ ) and from $\mathrm{pH} 6.0$ to 10.5 (optimum $\mathrm{pH} 7 \cdot 0-8 \cdot 0)$. API ZYM kit gives positive results for alkaline phosphatase, esterase (C4), esterase lipase, valine arylamidase, leucine arylamidase, naphthol-AS-BI-phosphohydrolase, $\beta$-galactosidase and $N$-acetyl- $\beta$-glucosaminidase and negative results for lipase, cystine arylamidase, trypsin, $\alpha$-chymotrypsin, acid phosphatase, $\alpha$-galactosidase, $\beta$-glucuronidase, $\beta$-glucosidase, $\beta$-glucosidase, $\alpha$-mannosidase and $\alpha$-fucosidase. Agar, aesculin, starch, Tween 80 and Tween 20 are hydrolysed. Casein, gelatin, L-tyrosine and 
xanthine are not hydrolysed. Acids are produced from D-glucose, D-fructose, D-ribose, D-xylose, $\alpha$-D-lactose, maltose, D-trehalose, L-arabinose, raffinose, rhamnose, D-melibiose, D-mannose and sucrose, but not from D-mannitol, adonitol, glycerol or inositol. Shows agarolytic activity. Contains a large amount of phosphatidylethanolamine and a small amount of diphosphatidylglycerol as the polar lipids. The DNA G $+\mathrm{C}$ content is $58 \mathrm{~mol} \%$.

The type strain is strain $\mathrm{M} 18^{\mathrm{T}}\left(=\mathrm{KCTC} 12357^{\mathrm{T}}=\mathrm{DSM}\right.$ $\left.16975^{\mathrm{T}}\right)$, isolated from tidal flat sediment in Korea.

\section{Acknowledgements}

This work was supported by the 21C Frontier Microbial Genomics and Application Center Program, Ministry of Science \& Technology (grant MG05-0101-1-0), Republic of Korea.

\section{References}

Cowan, S. T. \& Steel, K. J. (1965). Manual for the Identification of Medical Bacteria. London: Cambridge University Press.

DeLong, E. F. (1992). Archaea in coastal marine environments. Proc Natl Acad Sci U S A 89, 5685-5689.

Distel, D. L., Morrill, W., MacLaren-Toussaint, N., Franks, D. \& Waterbury, J. (2002). Teredinibacter turnerae gen. nov., sp. nov., a dinitrogen-fixing, cellulolytic, endosymbiotic $\gamma$-proteobacterium isolated from the gills of wood-boring molluscs (Bivalvia: Teredinidae). Int J Syst Evol Microbiol 52, 2261-2269.

Ekborg, N. A., Gonzalez, J. M., Howard, M. B., Taylor, L. E., Hutcheson, S. W. \& Weiner, R. M. (2005). Saccharophagus degradans gen. nov., sp. nov., a versatile marine degrader of complex polysaccharides. Int J Syst Evol Microbiol 55, 1545-1549.

Felsenstein, J. (2002). PHYLIP - phylogeny inference package, version 3.6a. Distributed by the author. University of Washington, Seattle, USA.

Gauthier, M. J., Lafay, B., Christen, R., Fernandez, L., Acquaviva, M., Bonin, P. \& Bertrand, J.-C. (1992). Marinobacter hydrocarbonoclasticus gen. nov., sp. nov., a new, extremely halotolerant, hydrocarbondegrading marine bacterium. Int J Syst Bacteriol 42, 568-576.

Gerhardt, P., Murray, R. G. M., Wood, W. A. \& Krieg, N. R. (1994). Phenotypic characterization. In Methods for General and Molecular Bacteriology, pp. 607-654. Edited by P. Gerhardt. Washington, DC: American Society for Microbiology.

González, J. M., Mayer, F., Moran, M. A., Hodson, R. E. \& Whitman, W. B. (1997). Microbulbifer hydrolyticus gen. nov., sp. nov. and Marinobacterium georgiense gen. nov., sp. nov., two marine bacteria from a lignin-rich pulp mill waste enrichment community. Int J Syst Bacteriol 47, 369-376.

Gorshkova, N. M., Ivanova, E. P., Sergeev, A. F., Zhukova, N. V., Alexeeva, Y., Wright, J. P., Nicolau, D. V., Mikhailov, V. V. \& Christen, R. (2003). Marinobacter excellens sp. nov., isolated from sediments of the Sea of Japan. Int J Syst Evol Microbiol 53, 2073-2078.

Howard, M. B., Ekborg, N. A., Taylor, L. E., II, Weiner, R. M. \& Hutcheson, S. W. (2004). Chitinase B of "Microbulbifer degradans" 2-40 contains two catalytic domains with different chitinolytic activities. J Bacteriol 186, 1297-1303.

Huu, N. B., Denner, E. B. M., Ha, D. T. C., Wanner, G. \& Stan-Lotter, H. (1999). Marinobacter aquaeolei sp. nov., a halophilic bacterium isolated from a Vietnamese oil-producing well. Int J Syst Bacteriol 49, 367-375.
Kimura, M. (1980). A simple method for estimating evolutionary rates of base substitutions through comparative studies of nucleotide sequences. J Mol Evol 16, 111-120.

Komagata, K. \& Suzuki, K. (1987). Lipid and cell-wall analysis in bacterial systematics. Methods Microbiol 19, 161-208.

Lanyi, B. (1987). Classical and rapid identification methods for medically important bacteria. Methods Microbiol 19, 1-67.

Lee, E. M., Jeon, C. O., Choi, I., Chang, K.-S. \& Kim, C.-J. (2005). Silanimonas lenta gen. nov., sp., nov., a slightly thermophilic and alkaliphilic gammaproteobacterium isolated from a hot spring. Int J Syst Evol Microbiol 55, 385-389.

Leifson, E. (1963). Determination of carbohydrate metabolism of marine bacteria. J Bacteriol 85, 1183-1184.

Marquez, M. C. \& Ventosa, A. (2005). Marinobacter hydrocarbonoclasticus Gauthier et al. 1992 and Marinobacter aquaeolei Nguyen et al. 1999 are heterotypic synonyms. Int J Syst Evol Microbiol 55, 1349-1351.

Martín, S., Márquez, M. C., Sánchez-Porro, C., Mellado, E., Arahal, D. R. \& Ventosa, A. (2003). Marinobacter lipolyticus sp. nov., a novel moderate halophile with lipolytic activity. Int J Syst Evol Microbiol 53, 1383-1387.

Romanenko, L. A., Schumann, P., Rohde, M., Zhukova, N. V., Mikhailov, V. V. \& Stackebrandt, E. (2005). Marinobacter bryozoorum sp. nov. and Marinobacter sediminum sp. nov., novel bacteria from the marine environment. Int J Syst Evol Microbiol 55, 143-148.

Rossello-Mora, R. \& Amann, R. (2001). The species concept for prokaryotes. FEMS Microbiol Rev 25, 39-67.

Satomi, M., Kimura, B., Hayashi, M., Shouzen, Y., Okuzumi, M. \& Fujii, T. (1998). Marinospirillum gen. nov., with descriptions of Marinospirillum megaterium sp. nov., isolated from kusaya gravy, and transfer of Oceanospirillum minutulum to Marinospirillum minutulum comb. nov. Int J Syst Bacteriol 48, 1341-1348.

Satomi, M., Kimura, B., Hayashi, M., Okuzumi, M. \& Fujii, T. (2004). Marinospirillum insulare sp. nov., a novel halophilic helical bacterium isolated from kusaya gravy. Int J Syst Evol Microbiol 54, 163-167.

Shivaji, S., Gupta, P., Chaturvedi, P., Suresh, K. \& Delille, D. (2005). Marinobacter maritimus sp. nov., a psychrotolerant strain isolated from sea water off the subantarctic Kerguelen islands. Int J Syst Evol Microbiol 55, 1453-1456.

Stackebrandt, E., Frederiksen, W., Garrity, G. M. \& 10 other authors (2002). Report of the ad hoc committee for the re-evaluation of the species definition in bacteriology. Int J Syst Evol Microbiol 52, 1043-1047.

Tamaoka, J. \& Komagata, K. (1984). Determination of DNA base composition by reverse-phase high-performance liquid chromatography. FEMS Microbiol Lett 25, 125-128.

Thompson, J. D., Higgins, D. G. \& Gibson, T. J. (1994). CLUSTAL W: improving the sensitivity of progressive multiple sequence alignment through sequence weighting, position-specific gap penalties and weight matrix choice. Nucleic Acids Res 22, 4673-4680.

Yoon, J. H., Kim, I. G., Shin, D. Y., Kang, K. H. \& Park, Y. H. (2003a). Microbulbifer salipaludis sp. nov., a moderate halophile isolated from a Korean salt marsh. Int J Syst Evol Microbiol 53, 53-57.

Yoon, J. H., Kim, H., Kang, K. H., Oh, T.-K. \& Park, Y. H. (2003b). Transfer of Pseudomonas elongata Humm 1946 to the genus Microbulbifer as Microbulbifer elongatus comb. nov. Int J Syst Evol Microbiol 53, 1357-1361.

Yoon, J. H., Kim, I. G., Oh, T. K. \& Park, Y. H. (2004). Microbulbifer maritimus sp. nov., isolated from an intertidal sediment from the Yellow Sea, Korea. Int J Syst Evol Microbiol 54, 1111-1116. 